MINERALOGIA, 49, No 1-4: 35-45 (2018)

DE DE GRUYTER

DOI: 10.2478/mipo-2018-0004

www.Mineralogia.pl

MineRalogical SOCIETY of Poland

PolskiE TOWARZYSTWO MINERALOGICZNE

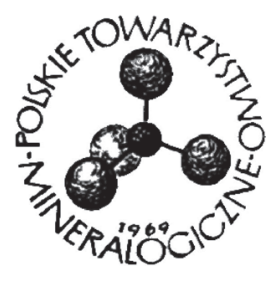

Original paper

\title{
Coke and coal as reductants in manganese ore smelting: An experiment
}

\author{
Bambang Suharno ${ }^{1,{ }^{*} a}$, Fajar Nurjaman ${ }^{2,{ }^{*}}$; Achmad Rifki ${ }^{1,{ }^{*} c}$, Robby Krisnaldo \\ Elvin $^{1,{ }^{*}}$, Alif Ardiansyah Putra ${ }^{1, * e}$, Deni Ferdian ${ }^{1,{ }^{* f}}$ \\ ${ }^{1}$ Department of Metallurgy and Materials Engineering, Universitas Indonesia, Depok-16424, Indonesia \\ ${ }^{2}$ Research Unit for Mineral Technology, Indonesian Institute of Sciences, Lampung-35361, Indonesia \\ * Corresponding authors

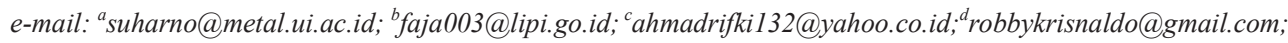 \\ ealifardiansyahputra@gmail.com, ${ }^{f}$ deni@metal.ui.ac.id
}

Received: July 19, 2017

Received in revised form: March 26, 2018

Accepted: March 27, 2018

Available online: April 15, 2018

\begin{abstract}
The effect of coke and bituminous coal on the reduction of medium-grade manganese ore in ferromanganese production was investigated. Charges of $30 \mathrm{~kg}$ medium grade manganese ore, $12 \mathrm{~kg}$ limestone and varied amounts of coke and coal were smelted in a Submerged Electric Arc Furnace (SAF) at temperatures of $1300^{\circ} \mathrm{C}$ to $1500^{\circ} \mathrm{C}$. The composition of the ferromanganese and the slag were determined by X-Ray Fluorescence. It was found that using coke as a single reductant resulted in a $96 \%$ yield of ferromanganese which was higher than by using coal either as a single reductant or in a mixture of coal and coke. It was also found that using coke as a single reductant resulted in the lowest specific energy consumption. Using coal as reductant produced ferromanganese containing high sulfur and phosphorus.
\end{abstract}

Key-words: ferromanganese, manganese ore, coke, coal, Submerged Electric Arc Furnace (SAF)

\section{Introduction}

About $90 \%$ of all manganese products are consumed in steel industries as ferromanganese (Tangstad, Olsen 1995; Çardakli et al. 2011; Ahmed et al. 2014). It can be produced either by using blast furnaces or electric arc furnaces. Today, almost 6 million ton of ferromanganese in the world is produced mostly using Submerged Electric Arc Furnaces 
(SAF; Gokarn 2012; Kunze, Degel 2004; Steenkamp, Basson 2013) as shown in Figure 1 due to their ability to provide better energy efficiency than blast furnaces. In SAF, the electrodes are buried deep in the furnace charge and the reduction process takes place near the tip of the electrodes. The current flow between electrodes creates the intense heat required for the high temperature and the energy for the reduction reactions.
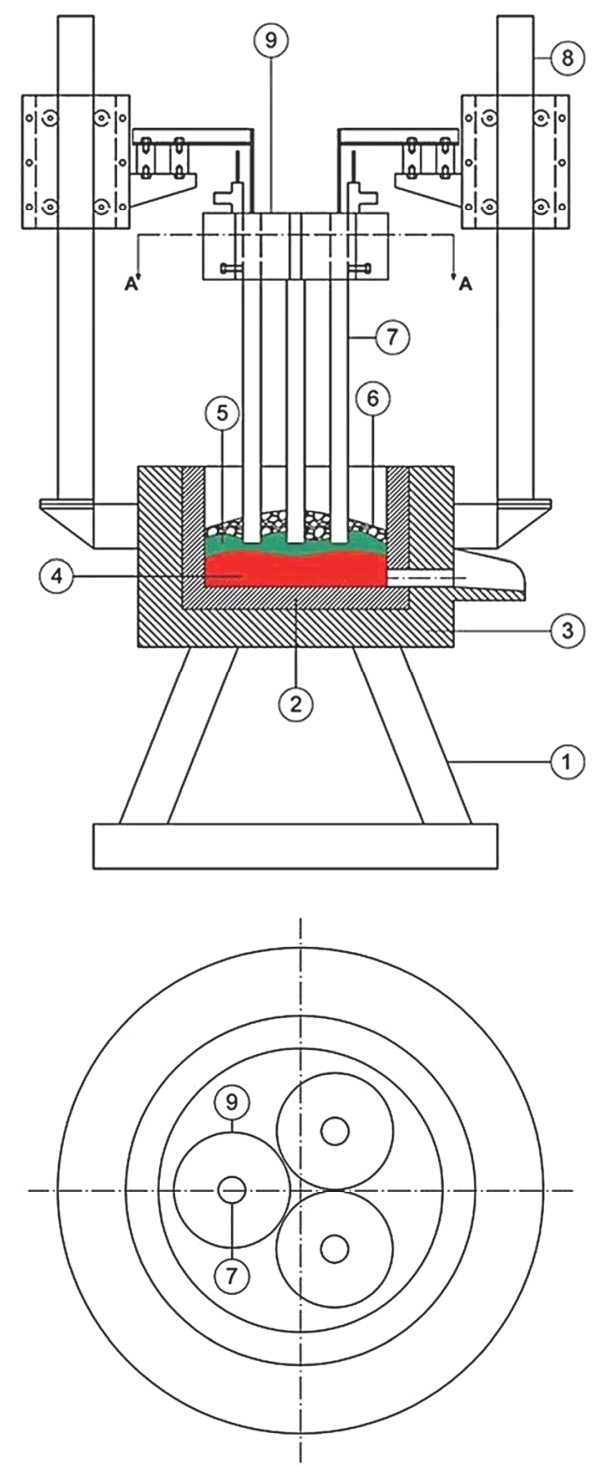

Fig. 1. Schematic of Submerged Arc Furnace (SAF): (a) Side view; (b) cross section of A-A (top view). (1) SAF support; (2) magnesia refractory; (3) alumina refractory; (4) FeMn; (5) slag; (6) manganese ore, coke, and limestone; (7) electrodes; (8) electrodes rail; (9) electrodes holder. 
During ferromanganese production, some parameters such as temperature, time, and charge basicity affect manganese recovery. A previous study showed that an increase in these parameters increased the extent of the carbothermal reduction process, thus increasing manganese recovery (Ahmed et al. 2014).

The main role of the carbonaceous reducing materials in the production of ferroalloys is to reduce the oxide compounds such as $\mathrm{MnO}_{2}, \mathrm{Cr}_{2} \mathrm{O}_{3}, \mathrm{Fe}_{2} \mathrm{O}_{3}$ in the mineral ore, either by the bouduard reaction or by direct reduction. As it was reported that the Boudouard reaction involving carbon monoxide (Eq. 1) is less important in the reduction of manganese ore using SAF, it was replaced by carbon (direct) reduction in the manganese ore smelting process (Eq.2; Chukwuleke et al. 2009). Thus, the selection of carbonaceous reducing materials plays an important role in ferromanganese production due to its function in direct reduction.

$$
\begin{gathered}
\mathrm{MO}+\mathrm{CO} \rightarrow \mathrm{M}+\mathrm{CO}_{2} \\
\mathrm{MO}+\mathrm{C} \rightarrow \mathrm{M}+\mathrm{CO}
\end{gathered}
$$

Coke, which is commonly used as a reductant in ferromanganese production, is expensive. Using coal rather than coke as a reductant reduces cost but creates a pollution problem (Vorob'ev et al. 2009). Today, there is still less information about the use of coal, especially bituminous coal, as a reductant, especially for smelting the medium-grade manganese ore to produce ferromanganese.

In this paper, the effect of coke and coal as reductants on the quality of ferromanganese, especially regarding manganese, sulfur and phosphorus contents, and other parameters such as product yield and specific energy consumption, is examined.

\section{Experimental}

In the experiment, $30 \mathrm{~kg}$ of manganese ore from East Java-Indonesia were blended with different- and varied amounts of reductants, namely, coke and coal. $12 \mathrm{~kg}$ of limestone was added as a flux to produce ferromanganese alloy containing at least $60 \% \mathrm{Mn}$. All the compositions in the experiment are shown in Table 1 . The compositions of the manganese ore and limestone were determined by X-Ray Fluorescence (XRF), as shown in Table 2. The compositions of the coke and coal were characterized by using gravimetry, XRF analyzer, and bomb calorimetre for proximate analysis, ash content and calorific value, respectively, as shown in Table 3. The composition of the limestone used is shown in Table 4.

The size range of the manganese ore, coke, coal and limestone that was fed through the open-top of SAF, as shown in Figure 2, was 30-40 mm, 20-35 mm, 25-40 mm, and 20$35 \mathrm{~mm}$, respectively. Each trial smelting was carried out for 60 minutes, the current was 500 to $1000 \mathrm{~A}$, and the pouring temperature was $1300^{\circ} \mathrm{C}$ to $1500^{\circ} \mathrm{C}$. The molten ferromanganese and slag were poured together into a sand mould. The ferromanganese and the slag would separate due to their different densities. The compositions of the ferromanganese and the slag were analyzed by XRF. 
Compositions of materials used in ferromanganese-production experiment.

\begin{tabular}{lllllll}
\hline $\begin{array}{l}\text { Trial } \\
\text { No. }\end{array}$ & $\begin{array}{l}\text { Manganese Ore } \\
(\mathrm{Kg})\end{array}$ & $\begin{array}{l}\text { Limestone } \\
(\mathrm{Kg})\end{array}$ & $\begin{array}{l}\text { Coke } \\
(\mathrm{Kg})\end{array}$ & $\begin{array}{l}\text { Coal } \\
(\mathrm{Kg})\end{array}$ & $\begin{array}{l}\text { Total Fix } \\
\text { Carbon }(\mathrm{Kg})\end{array}$ & Reductants \\
\hline 1 & 30 & 12 & 5.5 & 0 & 4.5 & Coke \\
2 & 30 & 12 & 7.5 & 0 & 6 & \\
3 & 30 & 12 & 9.5 & 0 & 8 & \\
4 & 30 & 12 & 11.5 & 0 & 9.5 & Coal \\
\hline 5 & 30 & 12 & 0 & 12.1 & 6 & \\
6 & 30 & 12 & 0 & 14.1 & 7 & \\
7 & 30 & 12 & 0 & 16.1 & 8 & $(25 \%$ coke- $75 \%$ coal $)$ \\
8 & 30 & 12 & 0 & 18.1 & 9.5 & $(50 \%$ coke-50\% coal $)$ \\
\hline 9 & 30 & 12 & 2.4 & 12.1 & 8 & $(75 \%$ coke- $25 \%$ coal $)$ \\
\hline
\end{tabular}

TABLE 2

The chemical composition of the manganese ore.

\begin{tabular}{llllllll}
\hline Composition & $\mathrm{MnO}_{2}$ & $\mathrm{Fe}_{2} \mathrm{O}_{3}$ & $\mathrm{Mn}$ & $\mathrm{Fe}$ & $\mathrm{SiO}_{2}$ & $\mathrm{Al}_{2} \mathrm{O}_{3}$ & $\mathrm{CaO}$ \\
\hline \% wt. & 62.3 & 8 & 39.4 & 2.8 & 26.6 & 1.8 & 0.9 \\
\hline
\end{tabular}

TABLE 3

Compositions of the reductants.

\begin{tabular}{lll}
\hline Composition & Coke & Coal \\
\hline Fixed Carbon (\% wt.) & 84.69 & 47.74 \\
Moisture (\% wt.) & 1.91 & 6.72 \\
Volatile Matter (\% wt.) & 2.06 & 21.14 \\
Ash (\%wt.) & 11.89 & 24.41 \\
$-\quad \mathrm{SiO}_{2}$ & 82.63 & 89.35 \\
$-\quad \mathrm{Al}_{2} \mathrm{O}_{3}$ & 16.99 & 10.39 \\
$-\quad \mathrm{P}_{2} \mathrm{O}_{5}$ & 0.38 & 0.26 \\
Sulfur (\% wt.) & 0.97 & 1.06 \\
Calorific value (Cal/gr) & 7816 & 5900 \\
\hline
\end{tabular}


Chemical composition of the limestone.

\begin{tabular}{lllll}
\hline Composition & $\mathrm{MnO}$ & $\mathrm{SiO}_{2}$ & $\mathrm{CaCO}_{3}$ & $\mathrm{P}_{2} \mathrm{O}_{5}$ \\
\hline$\% \mathrm{wt}$ & 0.013 & 2.2 & 73.72 & 0.38 \\
\hline
\end{tabular}

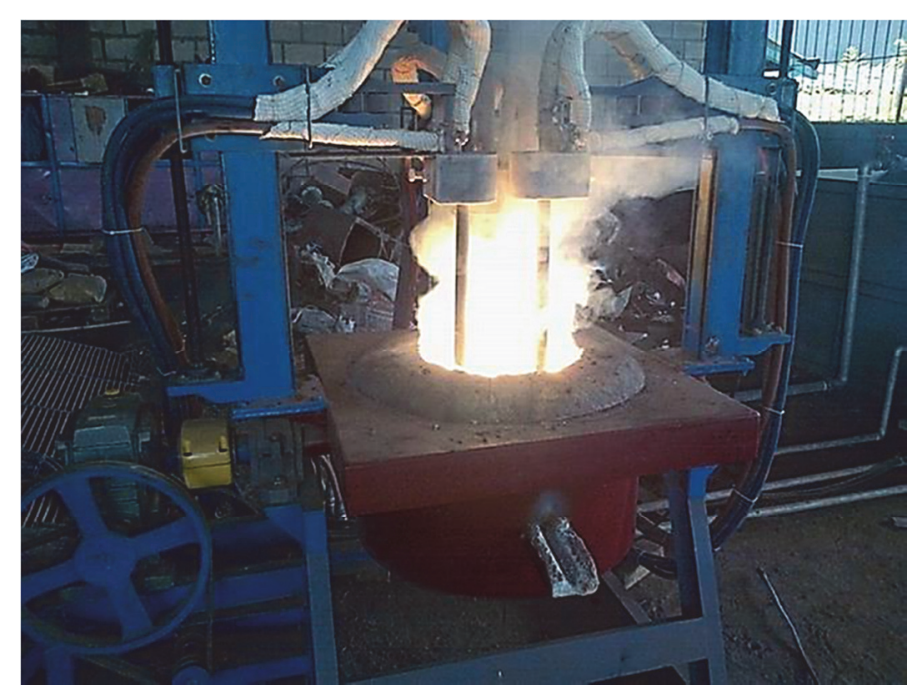

Fig. 2. Submerged Arc Furnace (SAF).

\section{Result and Discussion}

\subsection{Effect of coke and coal on Mn-content, Mn-recovery and the amount of ferromanganese}

The quality of the ferromanganese was determined by manganese content (Çardakli et al. 2011; Ahmed et al. 2014; Chukwuleke et al. 2009). According to ASTM A-99, the minimum percentage of manganese or Mn-content in ferromanganese is $60 \%$. All the ferromanganese produced in this experiment exceeded $60 \%$ (Fig. 3). This was because the medium-grade manganese ore used in this experiment had the minimum $\mathrm{Mn} / \mathrm{Fe}$ requirement for ferromanganese production, i.e. 6.0. However, the use of coke rather than coal as a reductant led to the production of a higher quantity and the Mn content of ferromanganese (Fig. 3).

From Table 5, the Mn recovery was increased by increasing the total fixed carbon in coke and coal reductant, but slightly decreased when $9.5 \mathrm{~kg}$ of coal reductant was added to the total fixed carbon. The more reductant addition, the more manganese oxide in the manganese ore was reduced to manganese, and the more iron oxide was reduced to iron. Thus, the manganese content in the ferromanganese was reduced by the increasing iron. 


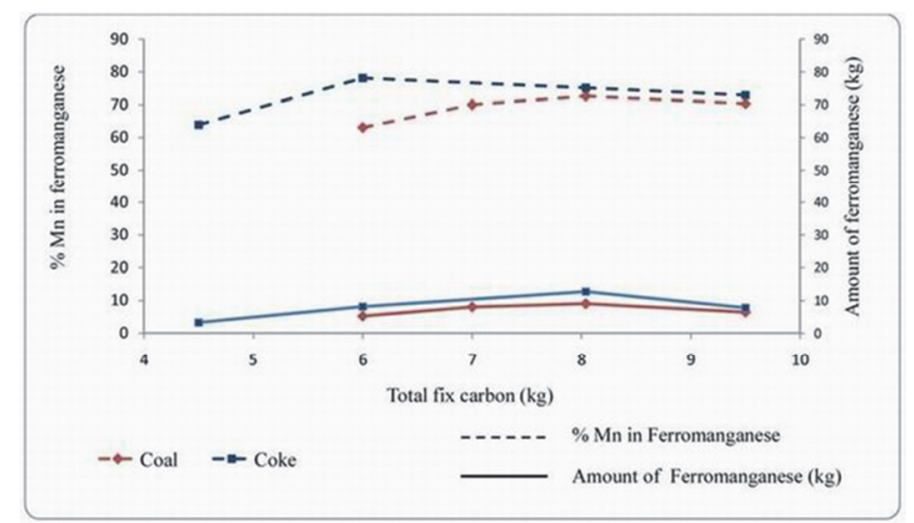

Fig. 3. Effect of coke and coal on Mn-content and the amount of ferromanganese.

TABEL 5

Summary results of manganese ore-smelting process with various reductants.

\begin{tabular}{|c|c|c|c|c|c|c|c|c|}
\hline \multirow[t]{2}{*}{ Fix Carbon $(\mathrm{Kg})$} & \multicolumn{5}{|c|}{ Ferromanganese } & \multirow{2}{*}{$\begin{array}{l}\text { Spec. Energy } \\
(\mathrm{kWh} / \mathrm{kg})\end{array}$} & \multirow{2}{*}{$\begin{array}{l}\text { Yield } \\
(\%)\end{array}$} & \multirow{2}{*}{$\begin{array}{l}\text { Mn } \\
\text { Recovery }\end{array}$} \\
\hline & $\begin{array}{l}\mathrm{Mn} \\
(\%)\end{array}$ & $\begin{array}{l}\mathrm{Fe} \\
(\%)\end{array}$ & $\begin{array}{l}\text { Amount } \\
(\mathrm{Kg})\end{array}$ & $\mathrm{P}$ & $\mathrm{S}$ & & & \\
\hline \multicolumn{9}{|l|}{ Reductant: coke } \\
\hline 4,5 & 63.94 & 30.78 & 3.35 & 0.14 & 0.1 & 18.99 & 25.02 & 39.79 \\
\hline 6 & 78.13 & 12.65 & 8.2 & 0.25 & 0.001 & 9.80 & 58.69 & 78.24 \\
\hline 7 & - & - & - & - & - & - & - & - \\
\hline 8 & 75.19 & 20.17 & 12.8 & 0.001 & 0,18 & 7.03 & 96.24 & 80.08 \\
\hline 9,5 & 72.99 & 13.93 & 7.8 & 0.15 & 0.001 & 11.23 & 53.46 & 94.96 \\
\hline \multicolumn{9}{|l|}{ Reductant: coal } \\
\hline 4,5 & - & - & - & - & - & - & - & - \\
\hline 6 & 63.12 & 26.5 & 5.3 & 0.38 & 0.41 & 12.45 & 40.19 & 83.53 \\
\hline 7 & 70.05 & 15.96 & 8.1 & 0.64 & 0.27 & 7.56 & 47.18 & 89.78 \\
\hline 8 & 72.65 & 16.85 & 9.1 & 0.74 & 0.90 & 7.91 & 68.92 & 93.30 \\
\hline 9,5 & 70.38 & 15.4 & 6.5 & 0.45 & 0.38 & 8.68 & 47.18 & 81.87 \\
\hline \multicolumn{9}{|c|}{ Reductant: mixture (coke and coal) } \\
\hline $8(25 \%$ coke $-75 \%$ coal $)$ & 64.26 & 20.09 & 8.5 & 0.53 & 0.43 & 7.69 & 60.43 & $\begin{array}{l}87.0 \\
0\end{array}$ \\
\hline $8(50 \%$ coke $-50 \%$ coal $)$ & 68.44 & 21.73 & 8 & 0.28 & 0.21 & 7.76 & 51.88 & 86.05 \\
\hline $8(75 \%$ coke $-25 \%$ coal $)$ & 78.8 & 12.2 & 9.1 & 0.4 & 0.16 & 10.50 & 64.22 & 77.48 \\
\hline
\end{tabular}

Carbon is used to reduce the manganese oxide to manganese by the direct reduction process. Although the coke and the coal had the same total fixed carbon content in each trial, coke has a higher calorific value and a lower volatile-matter content compared to coal (Table 3). When using coal as a single reductant, the volatile matter is changed into gas in an endothermic reaction. Thus, the energy from coal combustion was used not only for the reduction of manganese oxide, but also for releasing the volatile matter. The stoichiometry for coke in this smelting process was $5.5 \mathrm{~kg}$ (Trial 1), but it showed the lowest manganese content and the lowest amount of ferromanganese. The highest manganese content in 
ferromanganese, i.e. $78.13 \% \mathrm{Mn}$, resulted from using as much as $7.5 \mathrm{~kg}$ of coke $(6 \mathrm{~kg}$ of fixed carbon) as a single reductant. The largest amount of ferromanganese, i.e. $12 \mathrm{~kg}$, was obtained using $9.5 \mathrm{~kg}$ of coke (8 $\mathrm{kg}$ fixed carbon). However, when more than $9.5 \mathrm{~kg}$ of coke ( $8 \mathrm{~kg}$ of fixed carbon) and $16.1 \mathrm{~kg}$ of coal ( $8 \mathrm{~kg}$ fix carbon) were used, the Mn-content and the amount of ferromanganese decreased. Too much excess reductant means that too much energy was used in ferromanganese production, and thus had a negative effect on the quality and quantity of ferromanganese produced. The results of this experiment are in agreement with those of Vorob'ev et al. (2009); the loss of manganese was increased by the increase of the melting point of the slag and ferromanganese due to manganese vaporization.

\subsection{Effect of coke and coal on yield in ferromanganese production}

Yield is an important factor in determining the efficiency of any smelting process. The percentage yield can be calculated using the mass of the actual product obtained divided by the theoretical mass of the raw material (Eissa et al. 2012). In this ferromanganeseproduction experiment, the yield is expressed as the ratio between the amount of $\mathrm{Fe}$ and $\mathrm{Mn}$ in ferromanganese product and the manganese ore which was used as a parameter of the efficiency of the process. It is evident from Figure 4 that using coke as a reductant resulted in a better yield than using coal; the coke had a better reduction rate than coal, as explained above. The highest yield, i.e. $96.24 \%$, was obtained by smelting $30 \mathrm{~kg}$ of medium-grade manganese ore using $11.5 \mathrm{~kg}$ of coke (9.5 kg of fixed carbon). Both for coke and coal, the yield increased until the total amount of fixed carbon reached $8.0 \mathrm{~kg}$. Further carbon addition decreased the yield significantly. In this case, too much reductant was a negative influence on yield.

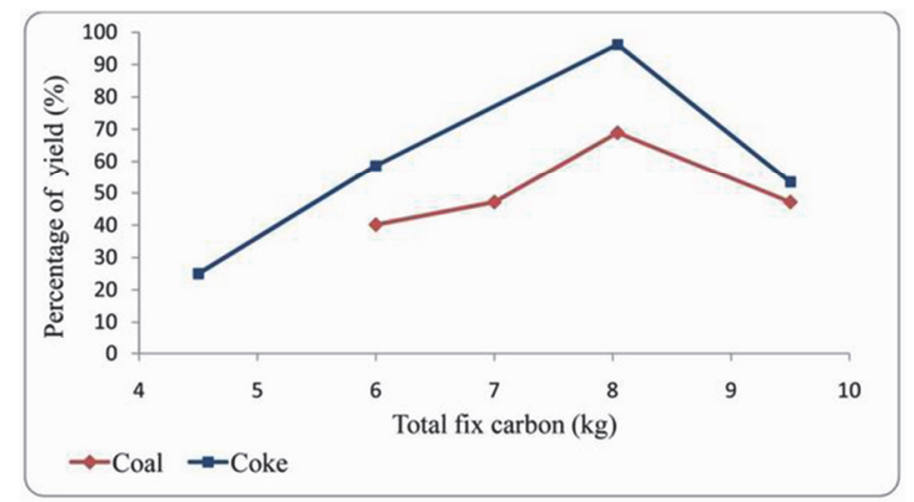

Fig. 4. Effect of coke and coal on yield of produced ferromanganese.

\subsection{Effect of coke and coal on energy consumption in ferromanganese production}

According to Eissa et al. (2012), with the addition of reductant, energy consumption or the specific energy of the ferromanganese smelting process increased too. In our 
experiment, the specific energy decreased with increasing reductant until it reached an optimum value, at which point it began to rise again. As shown in Figure 5, for coke as reductant, the optimum specific energy was $7.0 \mathrm{kWh} / \mathrm{kg}$ when $11.5 \mathrm{~kg}$ of coke $(9.5 \mathrm{~kg}$ of fixed carbon) were added whereas, for coal, the optimum specific energy of $7.56 \mathrm{kWh} / \mathrm{kg}$ was attained by adding $14.1 \mathrm{~kg}$ of coal ( $7 \mathrm{~kg}$ of fixed carbon).

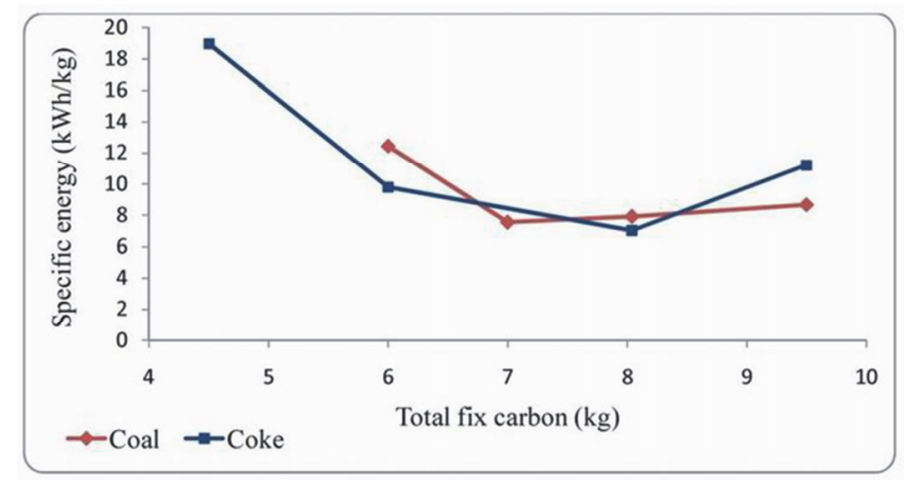

Fig. 5. Effect of coke and coal on specific energy of ferromanganese production.

\subsection{Effect of coke and coal on phosphorus and sulphur in ferromanganese product}

Phosphorus and sulfur are impurities which should be removed from manganese in the production of ferromanganese (Shim, Sano 1995; Hwang 2011; Chaudhary et al. 2007). The presence of sulfur and phosphorus will reduce the quality of steel, causing it to exhibit poor physical properties during rolling and forming. In the steelmaking process, the limitation of phosphorus and sulfur in the final steel products is controlled by selecting appropriate raw materials (Lagendijk et al. 2010); this includes ferroalloys added to molten steel.

The highest sulfur contents in ferromanganese were found when $9.5 \mathrm{~kg}$ of cokes $(8 \mathrm{~kg}$ of fixed carbon) and $16.1 \mathrm{~kg}$ of coals (8 $\mathrm{kg}$ of fixed carbon) were added (Fig. 6). From Figure 4, it is seen both of coke and coal produced the highest yield with the addition of $70 \%$ excess coke and coal. Thus, higher reduction rates of manganese oxide also promote the diffusion of sulfur from the raw materials into molten ferromanganese. Phosphorus in ferromanganese tended to increase with the addition of coke. For coal, phosphorous tended to increase with increasing fixed carbon up to $8 \mathrm{~kg}$ of fixed carbon above which, it tended to decrease.

The medium-grade manganese ore contained no phosphorus and no sulfur (Table 2). Nevertheless, the ferromanganese produced when using coal as reductant contained sulfur and phosphorus, more so than when using coke (Fig. 6). This was most probably due to coal containing more sulfur and phosphorus than coke (Table 3). Thus, in ferromanganese production, not only the ore but also the reductants should contain as little sulfur and phosphorus as possible. 


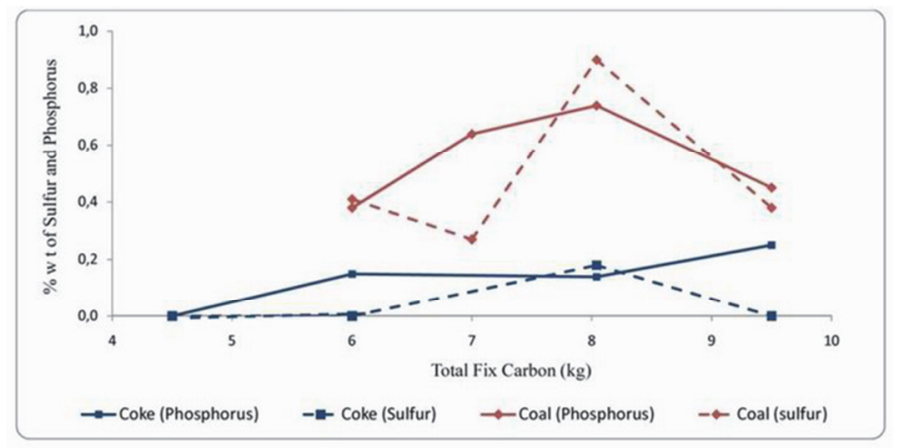

Fig. 6. Effect of coke and coal on phosphorus and sulfur contents in produced ferromanganese.

\subsection{Effect of mixed coke and coal on yield, manganese content and specific energy}

The optimum yield, quality and quantity of ferromanganese in the smelting experiment was obtained by using coke as reductant rather than coal. As coke is more expensive than coal, the mixing coke and coal is commonly done to reduce the cost of ferromanganese production. Lagendijk et al. (2010) reported that $77 \%$ Mn-content in FeMn was produced using a 30:70 mixture of anthracite and coke as reductants. In our study of mixed coke and bituminous-coal reductants, the sum of total fixed carbon added was $8 \mathrm{~kg}$, as the optimum of total fixed carbon from the single reductant, whether for coke and coal.

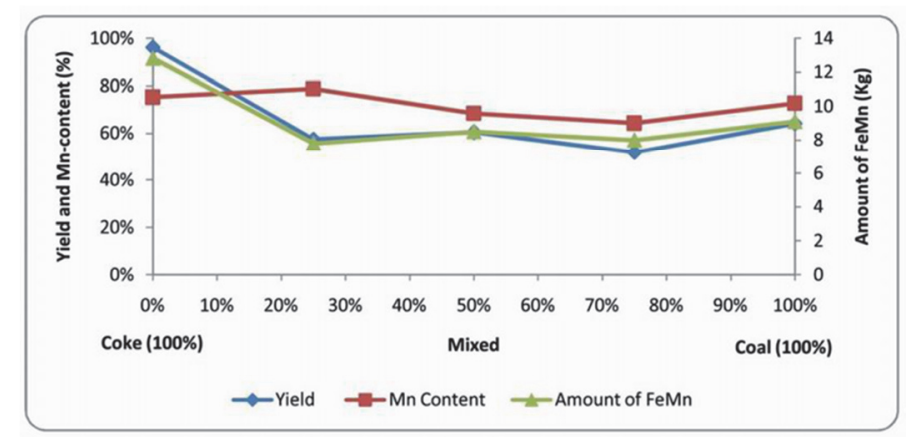

Fig. 7. Effect of mixed coke and coal on yield, Mn-content and amount of FeMn.

The yield and the amount of ferromanganese decreased as the proportion of coal was increased (Fig. 7). However, the optimum Mn-content (78.8\%) in the ferromanganese resulted from using a 25:75 mixture of bituminous coal and coke, i.e. slightly higher than that $(75.19 \%)$ resulting from the use of $100 \%$ coke as reductant. However, the bituminous coal had a higher ash content than the coke (Table 3). Thus, more coal in the mixture would add more non-metallic oxide compounds, e.g. $\mathrm{SiO}_{2}$ and $\mathrm{Al}_{2} \mathrm{O}_{3}$, and retard the reduction of metallic compounds during smelting. 


\section{Conclusions}

Medium-grade manganese ore, reduced by using coke and coal as reductants, produced ferromanganese with $63-78 \% \mathrm{Mn}$. The use of coke as a single reductant resulted in a higher percentage of manganese content and amount of ferromanganese product than by using coal as a single reductant. A higher yield and lower specific energy characterized ferromanganese production when using coke as reductant. The optimum coke addition was $9.5 \mathrm{~kg}$ ( $8 \mathrm{~kg}$ of fixed carbon) for smelting $30 \mathrm{~kg}$ of manganese ore with $12 \mathrm{~kg}$ of limestone. The use of coal as reductant would result in ferromanganese containing phosphorus and sulfur in greater amounts than by using coke.

Acknowledgments. The authors wish to thank the Research Unit for Mineral Technology-Indonesian Institute of Sciences and DRPM Universitas Indonesia for the facilities and financial support given for this project.

\section{References}

Ahmed, A., Haifa, H., El-Fawakhry, M. K., El-Faramawy, H \& Eissa M. (2014). Parameters affecting energy consumption for producing high carbon ferromanganese in a closed submerged arc furnace. Journal of Iron and Steel Research, International, 21(7), 1-20. DOI:10.1016/S1006-706X(14)60103-5

Çardakli, I. S., SevInç, N., \& Öztürk, T. (2011). Production of high carbon ferromanganese from a manganese ore located in Erzincan. Turkish Journal of Engineering and Environmental Sciences, 35(1), 31-38. DOI:10.3906/muh-1009-6.

Chaudhary, P. N., Minj, R. K., \& Goel, R. P. (2007). Development of a process for dephosphorisation of high carbon ferromanganese. Proceedings-International Ferro-Alloys Congress (INFACON) XI, 18-21 February 2007 (pp. 288-296). New Delhi - India. The Indian Ferro Alloy Producers’ Association (IFAPA).

Chukwuleke, O. P., Cai, J., Chukwujekwu, S., \& Xiao, S. (2009). Shift from coke to coal using direct reduction method and challenges. Journal of Iron and Steel Research, International, 16(2), 1-5. DOI: 10.1016/S1006706X(09)60018-2.

Eissa, M., El-faramawy, H., Ahmed, A., \& Nabil, S. (2012). Parameters affecting the production of high carbon ferromanganese in closed submerged arc furnace. Journal of Minerals \& Materials Characterization \& Engineering, 11(1), 1-20. DOI:10.4236/jmmce.2012.111001.

Gokarn, P. (May 20, 2012). Ferro Alloy Perspective or Steelmaker. Published in: https:/www.slideshare.net/prabhashgokarn/ferro-alloy-perspectives-for-the steelmaker?qid=3b96070d-78f743d1-8ea0-41d5d9b8f094\&v=\&b=\&from_search=44

Hurd, D., \& Kollar, J. (1991). Direct current electric arc furnaces. Pittsburgh, Pennsylvania: The EPRI Center for Materials Production (CMP-063).

Hwang, S. H. (2011). Phosphorus Removal From Manganese Ore by Plasma Treatment. Thesis, 2011, The University of Utah, United State of America.

Kunze, J., \& Degel, R. (2004). New trends in submerged arc furnace technology. Proceedings - International Ferro-Alloys Congress (INFACON) X. 1-4 February 2004 (pp. 444-454). Capetown-South Africa. Document Transformation Technologies (Doctech).

Lagendijk, H., Xakalashe, B., Ligege, T., Ntikang, P., \& Bisaka, K. (2010). Comparing manganese ferroalloy smelting in pilot-scale AC and DC submerged-arc furnaces. Proceedings - International Ferro-Alloys Congress (INFACON) XII, 6-9 June 2010 (pp. 498-508). Helshinki - Finland. Outotec Oyj.

Shim, S. C., \& Sano, N. (1995). Thermodynamics of phosphorus in carbon-saturated manganese-based alloys. Proceedings - International Ferro-Alloys Congress (INFACON) VII, 11-14 June 1995 (611-620). TrondheimNorway. The Norwegian Ferroalloy Research Organization (FFF).

Steenkamp, J. D., \& Basson, J. (2013). The manganese ferroalloys industry in southern Africa. The Journal of The Southern Africa Institute of Mining and Metallurgy, 113(8), 667-676. Available from: http://www.scielo.org.za/scielo.php?script=sci_arttext\&pid=S2225-62532013000800014\&lng=en\&nrm=iso>. ISSN 2411-9717. 
Tangstad, M., \& Olsen, S. E. (1995). The ferromanganese process-material and energy balance. Proceedings International Ferro-Alloys Congress (INFACON) VII, 1-14 June 1995 (pp. 621-630). Trondheim-Norway. The Norwegian Ferroalloy Research Organization (FFF).

Vorob'ev, V. P., Godunov, A. D., \& Ignat'ev, A. V. (2009). Production of manganese alloys from rich highbasicity ore. Steel in Translation, 39(3), 243-247. DOI: 10.3103/S0967091209030152. 